\title{
Assessment of Genetic Diversity Using ISSR Markers in Green Gram [Vigna radiata (L.) Wilczek]
}

\author{
Anamika Nath, S.R. Maloo, B.L. Meena*, A. Gangarani Devi and Sheetal Tak \\ Rajasthan College of Agriculture, MPUAT, Udaipur (Rajasthan) -313001, India \\ *Corresponding author
}

\begin{tabular}{|c|c|}
\hline & A B S T R A C T \\
\hline & \multirow{5}{*}{$\begin{array}{l}\text { Molecular characterization is helpful in understanding the phylogenetic relationship among } \\
\text { various germplasm to reveal the genetic diversity among the used parental genotypes. } \\
\text { Among several efficient methods for revealing genetic variability within and among plant } \\
\text { populations, one of the most widely applied methods is ISSR marker analysis. ISSR, } \\
\text { markers are commonly used because they are quick, simple and environment non-sensitive } \\
\text { enabling genetic diversity analysis in several types of plant material like natural } \\
\text { populations, population in breeding programmes. Evaluation of genetic diversity would } \\
\text { promote the efficient use of genetic variations, effective conservation and purity of the } \\
\text { genotype to be determined as well as utilization of germplasm in crop improvement. ISSR } \\
\text { marker analysis was performed to detect relatedness and diversity among eight parental } \\
\text { genotypes. ISSR markers are useful in detecting polymorphism among accessions by } \\
\text { generating a large number of markers that target multiple microsatellite loci distributed } \\
\text { across the genome. Out of } 109 \text { scorable bands, } 88 \text { bands were polymorphic and the level of } \\
\text { polymorphism was } 81 \text { per cent. Twenty five ISSR primers were used, out of which } \\
\text { eighteen primers showed amplification in all genotypes. The average number of bands per } \\
\text { primer was found to be } 6.22 \text { and average numbers of polymorphic bands per primer were } \\
4.89 \text {. ISSR-01 proved to be best primer in the present investigation with total } 29 \text { fragments } \\
\text { and eight highest scorable bands as well as } 100 \text { per cent polymorphism. }\end{array}$} \\
\hline $\begin{array}{l}\text { Ke y w or d s } \\
\text { Mungbean, ISSR } \\
\text { Markers, Yield and } \\
\text { yield components. }\end{array}$ & \\
\hline Article Info & \\
\hline $\begin{array}{l}\text { Accepted: } \\
\text { 12 April } 2017 \\
\text { Available Online: } \\
10 \text { May } 2017\end{array}$ & \\
\hline & \\
\hline
\end{tabular}

\section{Introduction}

Pulses offer one of the viable options for diversification of contemporary agriculture and management of natural resources. India is the largest producer and consumer of pulses in the world accounting 33 per cent of the area and 25 per cent of the global out-put. Green gram [Vigna radiata (L.) Wilczek) is the most important legume crop in India after chickpea and pigeonpea. It belongs to family Leguminaceae, subfamily Papillionaceae and its chromosome number is $2 \mathrm{n}=2 \mathrm{x}=22$. India is the primary green gram producer and contributes to about 75 per cent of the world pulses production. It contributes to about $14 \%$ of total pulses cultivation area and $7 \%$ of total pulses production in India. Green gram is extensively grown in India under varying soil types and climatic conditions and it improves soil fertility by fixing atmospheric nitrogen. It is a small herbaceous annual drought tolerant crop and suitable for dry land farming and predominantly used as intercrop with other crops. Being a short duration (60-65 days) crop with wide adaptability green gram grown 
all over the world as a sole crop and as an inter crop or mixed crop with cereals. Besides being a rich source of protein, green gram enriches soil fertility through atmospheric nitrogen fixation with the help of Rhizobium bacteria in nodules and humus thus, plays a crucial role in furthering sustainable agriculture. For any successful breeding programme to improve grain yield and component characters, it is essential to know precisely the genetic architecture of these characters under prevailing conditions. Application of molecular markers to plant breeding has established the need for information on variation in DNA sequence even in those crops in which little classical genetic and cytogenetic information is available. Currently, the genetic diversity of plants has been assessed more efficiently after the introduction of the methods that reveal polymorphism directly at the DNA levels.

\section{Materials and Methods}

Final experimental trial comprising 8 parents along with $28 \quad \mathrm{~F}_{1} \mathrm{~s}$ was evaluated during kharif, 2014 in randomized block design with three replications at RCA college farm, MPUAT, UDAIPUR. Eight diverse and well adapted genotypes of green gram were selected as parents for crossing programme, namely IPM-99-125, BM-4, ML-131, IPM 02-03, PDM-139, RMG-1035, RMG-344 and RMG-1045 (Table 1). All recommended cultural practices and plant protection measures were adopted to raise a good crop. Molecular analysis using ISSR markers was done exclusively for the parental material only. D Molecular marker analysis was done for the parental material to see the diversity present among the parental material. NA extracted from different green gram cultivars were compared using ISSR methodology. The leaves were harvested after 21 days and DNA was isolated with the help of Doyle and Doyle, 1987 protocol. DNA was extracted from young leaves (3-4 weeks old) using CTAB method and was amplified by using decamer random oligonucleotide primer in a DNA thermo cycler (Biometra).

For the ISSR reactions, 25 primer pairs were used. The DNA content in $20 \mu \mathrm{l}$ of the reaction mixture was $50 \mathrm{ng}$. The sequences of these primers were purchased from Bangalore Genei Pvt. Ltd. The details of operon code sequence of the primer and $\mathrm{G}: \mathrm{C}$ contents are given on table 3 . The reaction contained $10 \mathrm{X}$ reaction buffer, $200 \mu \mathrm{M}$ each of dNTPs ("Bangalore Genei"), $0.5 \mu \mathrm{M}$ of each primer and 1 unit of Taq DNA polymerase (Table 2 and Fig. 1).

Submerged gel electrophoresis unit was used for fractionating amplified PCR products on $1.2 \%$ agarose gel. The gel was prepared in $1 \mathrm{X}$ TAE buffer containing $0.5 \mu \mathrm{g} / \mathrm{ml}$ of ethidium bromides. The samples and loading dye were mixed in $1: 1$ ratio and loaded with micropipette. In order to score and preserve banding patterns, photographs of the gel were taken by a Gel Documentation System, under UV transilluminator.

ISSR bands were designated on the basis of their molecular size ranging between 1001000 bp. Electrophoresis was carried out at $100 \mathrm{~V}$ for $3 \mathrm{hr}$ in $1 \mathrm{X}$ TAE electrophoresis buffer.

Gel was viewed under UV transilluminator and photographed by gel documentation system. Presence of amplified products was scored as 1 and its absence as 0 for all genotypes and primer combinations. These data matrices were then entered into NTSYSPC developed by Rohlf (1993). The genetic distances obtained from cluster analysis through UPGMA were used to construct the dendrogram, depicting the relationships of the genotypes using computer program NTSYSpc version 2.02 . 


\section{Results and Discussion}

Total genomic DNA was isolated with CTAB method Doyle and Doyle (1987). The powdered plant tissues extracted with extraction buffer containing chelating agent (EDTA) which helped to inactivate nucleases released from the plant cells which could cause serious degradation of the genomic DNA. The amount of DNA isolated from various genotypes of $V$. radiata $\mathrm{L}$. ranged from 757 to $1518 \mathrm{ng} / \mu \mathrm{l}$. The genotype IPM 02-03 yielded the highest amount of DNA $(1518 \mathrm{ng} / \mu \mathrm{l})$. Whereas the lowest amount of DNA (757 $\mathrm{ng} / \mu \mathrm{l})$ was obtained from genotype RMG-344.

The ratio of absorbance (A260/A280) ranged from 1.70 to 1.89 revealing that the DNA obtained was free from contaminants like polysaccharides, protein and RNA. The quality of DNA as also checked by gel electrophoresis revealed a single discrete band in all genotypes showing that genomic DNA was intact and had high molecular weight, free from any mechanical or enzymatic degradation, free from RNA contamination and was of high quality (Table 5).

Twenty five ISSR primers were used for the present investigation out of which eighteen primers showed amplification in all genotypes (Fig. 2). A total of 112 amplified bands were obtained from the 18 primers, out of which 88 were polymorphic. The total number of amplified bands varied between 5 and 8 (Table 3). The average number of bands per primer was found to be 6.22 and average numbers of polymorphic bands per primer were 4.89 .

The polymorphism percentage ranged from $43 \%$ (UBC-845) to $100 \%$ for five primers (ISSR-01, UBC-817, UBC-818, UBC-820 and UBC-854) used. Average polymorphism across all the genotypes of $V$. radiata $\mathrm{L}$. was found to be $79 \%$. Overall size of PCR amplified products ranged between $100 \mathrm{bp}$ to 2000 bp. The PCR amplification using ISSR primers gave rise to reproducible amplification products. The number of potential ISSR markers depends on the variety and frequency of microsatellites, which tends to change with species (Table 6). Similar results were shown by Das et al., (2014), Singh et al., (2011) and Tantasawat et al., (2010).

Genetic relationship and cluster tree analysis

The data obtained by using ISSR primers were used to construct similarity matrix of eight $V$. radiata $\mathrm{L}$. genotypes using 'Simqual' sub-programme of software NTSYS-pc. Dendrograms were constructed using similarity matrix values as determined from ISSR data for $V$. radiata L. genotypes using unweighted pair group method with arithmetic average (UPGMA) sub-programme of NTSYS-pc software.

\section{Similarity matrix}

Based on ISSR similarity matrix data, the value of similarity coefficient ranged from 0.43 to 0.80 (Table 7). The average similarity across the eight parents was found out to be 0.62 showing that genotype were diverse from each other. Maximum similarity value of 0.80 was observed between genotypes RMG-1035 and RMG-1045 followed by RMG-1035 and RMG-344 with a similarity coefficient value of 0.79 . Likewise, minimum similarity value of 0.43 was observed between genotypes BM4 and IPM 02-03 and BM-4 with PDM-139 (44\%). Similar findings were reported by Das et al., (2014), Chattopadhyay et al., (2005), Datta and Lal (2011) and Singh et al., (2013) in green gram cultivars. 
Int.J.Curr.Microbiol.App.Sci (2017) 6(5): 1150-1158

Table.1 Experimental material and their pedigree

\begin{tabular}{lll}
\hline Parent & Pedigree & Source \\
\hline IPM 99-125 & PM 3 x APM 36 & IIPR, Kanpur \\
BM 4 & MUTANT of T44 & ARS, Badnapur \\
ML 131 & ML 1 x ML 23 & ARS, Durgapura \\
IPM 02-03 & IPM 99-125 x Pusa bold 2 & IIPR, Kanpur \\
PDM 139 & ML 20/19 x ML 5 & IIPR, Kanpur \\
RMG 1035 & RMG 492 x ML 818 & ARS, Durgapura \\
RMG 344 & MOONG SEL.1 x J 45 & ARS, Durgapura \\
RMG-1045 & RMG-62 x KM 2170 & ARS, Durgapura \\
\hline
\end{tabular}

Table.2 PCR reaction mixture content

\section{Components}

DNA template

Master Mixture

(i) dNTP MIX

(ii) Taq polymerase

(iii) Reaction buffer (10x)

(iv) Primer

(vi) dd $\mathrm{H}_{2} \mathrm{O}$
Final concentration

50ng

$2.00 \mu 1$
Single tube/20 $(\mu 1)$

$$
200 \mu \mathrm{M}
$$

$1.6 \mu 1$

$1 \mathrm{U}$

$0.33 \mu 1$

$1 \mathrm{X}$

$2.00 \mu 1$

$0.5 \mu \mathrm{M}$

$1.00 \mu 1$

$12.07 \mu 1$ 
Table.3 List of ISSR primers

\begin{tabular}{|c|c|c|c|c|c|c|c|}
\hline $\begin{array}{l}\text { SI } \\
\text { No }\end{array}$ & Primer & $\begin{array}{c}\text { Sequence } \\
\left(5^{\prime}-3^{\prime}\right)\end{array}$ & $\begin{array}{c}\text { Annealing } \\
\text { Temp. } \\
\text { (oC) }\end{array}$ & $\begin{array}{c}\text { No of } \\
\text { bands } \\
\text { (a) }\end{array}$ & $\begin{array}{c}\text { No. of } \\
\text { polymorphic } \\
\text { bands (b) }\end{array}$ & $\begin{array}{l}\text { Polymorphism } \\
\text { \% (b/a X 100) }\end{array}$ & $\begin{array}{l}\text { Range of } \\
\text { band size }\end{array}$ \\
\hline 1 & ISSR-01 & (GGC)5AT & 67.2 & 8 & 8 & 100 & $100-1500$ \\
\hline 2 & ISSR-02 & (AAG)5GC & 47.9 & 7 & 4 & 57 & $200-2000$ \\
\hline 3 & ISSR-03 & $(\mathrm{AAG}) 5 \mathrm{TC}$ & 45.5 & NA & NA & NA & \\
\hline 4 & ISSR-04 & $(\mathrm{AAG}) 5 \mathrm{CC}$ & 47.9 & 5 & 3 & 60 & $100-700$ \\
\hline 5 & ISSR-05 & (AGC) $5 \mathrm{CA}$ & 57.6 & 7 & 6 & 86 & $200-2000$ \\
\hline 6 & ISSR-06 & $(\mathrm{AGC}) 5 \mathrm{CG}$ & 60 & NA & NA & NA & \\
\hline 7 & ISSR-07 & (GGC)5TA & 67.2 & 8 & 6 & 75 & $100-1500$ \\
\hline 8 & ISSR-08 & (AGC)5GA & 57.6 & 8 & 7 & 88 & $100-1000$ \\
\hline 9 & ISSR-09 & $(\mathrm{AAG}) 5 \mathrm{CG}$ & 47.9 & 5 & 3 & 60 & $100-700$ \\
\hline 10 & ISSR-33 & (AG)8AT & 51.4 & NA & NA & NA & \\
\hline 11 & UBC-810 & (GA)8T & 43.3 & 7 & 4 & 57 & $300-1000$ \\
\hline 12 & UBC-811 & $(\mathrm{GA}) 8 \mathrm{C}$ & 43.5 & 7 & 6 & 86 & $300-1000$ \\
\hline 13 & UBC-813 & (CT) $8 \mathrm{~T}$ & 41.3 & NA & NA & NA & \\
\hline 14 & UBC-817 & (CA) $8 \mathrm{~A}$ & 45.8 & 5 & 5 & 100 & $200-600$ \\
\hline 15 & UBC-818 & (CA) $8 \mathrm{G}$ & 49.0 & 6 & 6 & 100 & $200-1000$ \\
\hline 16 & UBC-820 & (GT)8T & 53.3 & 5 & 5 & 100 & $100-700$ \\
\hline 17 & UBC-822 & (TC) $8 \mathrm{~A}$ & 51.9 & 7 & 5 & 71 & $100-1500$ \\
\hline 18 & UBC-824 & (TC) $8 \mathrm{G}$ & 43.3 & NA & NA & NA & \\
\hline 19 & UBC-836 & (AG)8YA & 45.0 & 5 & 4 & 80 & $300-900$ \\
\hline 20 & UBC-840 & (GA)8YT & 43.3 & NA & NA & NA & \\
\hline 21 & UBC-845 & (CT)8RG & 43.5 & 7 & 3 & 43 & $200-600$ \\
\hline 22 & UBC-848 & (CA)8RG & 41.3 & 5 & 4 & 80 & $300-1000$ \\
\hline 23 & UBC-854 & (TC)8RG & 52.7 & 6 & 6 & 100 & $200-1500$ \\
\hline 24 & UBC-873 & (GATA)4 & 45.8 & NA & NA & NA & \\
\hline 25 & UBC-878 & (GGC)5AT & 49 & 4 & 3 & 75 & $500-2000$ \\
\hline \multicolumn{4}{|c|}{ Total } & 112 & 88 & 79 & - \\
\hline \multicolumn{4}{|c|}{ Average } & 6.22 & 4.89 & - & - \\
\hline
\end{tabular}


Table.4 PCR reaction cycle

\begin{tabular}{lllllll}
\hline Cycle & \multicolumn{2}{l}{ Denaturation } & \multicolumn{2}{l}{ Annealing } & \multicolumn{2}{l}{ Extension } \\
\hline First cycle & $94^{\circ} \mathrm{C}$ & $5 \mathrm{~min}$ & - & - & - & - \\
$2-35$ Cycle & $94^{\circ} \mathrm{C}$ & $1 \mathrm{~min}$ & $\mathrm{Tm}(\mathrm{Pr})$ & $45 \mathrm{sec}$ & $72{ }^{\circ} \mathrm{C}$ & $2 \mathrm{~min}$ \\
Last cycle & - & - & - & - & $72^{\circ} \mathrm{C}$ & $10 \mathrm{~min}$ \\
\hline
\end{tabular}

Table.5 Quality and quantity of total genomic DNA of $V$. radiata L. isolated and purified by CTAB method

\begin{tabular}{cccc}
\hline Genotypes & Parents' Name & $\begin{array}{c}\text { Concentration } \\
(\mathbf{n g} / \boldsymbol{\mu l})\end{array}$ & Ratio 260/280 \\
\hline P1 & IPM 99-125 & 1420 & 1.81 \\
P2 & BM-4 & 968 & 1.77 \\
P3 & ML-131 & 1250 & 1.79 \\
P4 & IPM 02-03 & 1518 & 1.89 \\
P5 & PDM-139 & 1251 & 1.80 \\
P6 & RMG-1035 & 1012 & 1.81 \\
P7 & RMG-344 & 757 & 1.74 \\
P8 & RMG-1045 & 998 & 1.82 \\
\hline
\end{tabular}

Table.6 Details of the ISSR primers used for amplification of genomic DNA of green gram

Total number of primers 25

Number of primers which showed amplification

Number of primer which showed polymorphism

Total number of monomorphic bands

Total number of polymorphic bands

Total number of bands 
Table.7 Similarity matrix of green gram genotypes

\begin{tabular}{lcccccccc}
\hline & $\begin{array}{c}\text { IPM 99- } \\
\mathbf{1 2 5}\end{array}$ & $\begin{array}{c}\text { BM- } \\
\mathbf{4}\end{array}$ & $\begin{array}{c}\text { ML- } \\
\mathbf{1 3 1}\end{array}$ & $\begin{array}{c}\text { IPM 02- } \\
\mathbf{0 3}\end{array}$ & $\begin{array}{c}\text { PDM- } \\
\mathbf{1 3 9}\end{array}$ & $\begin{array}{c}\text { RMG- } \\
\mathbf{1 0 3 5}\end{array}$ & $\begin{array}{c}\text { RMG- } \\
\mathbf{3 4 4}\end{array}$ & $\begin{array}{c}\text { RMG- } \\
\mathbf{1 0 4 5}\end{array}$ \\
\hline IPM 99-125 & 1.00 & & & & & & \\
BM-4 & 0.49 & 1.00 & & & & & \\
ML-131 & 0.64 & 0.47 & 1.00 & & & & \\
IPM 02-03 & 0.49 & 0.43 & 0.54 & 1.00 & & & \\
PDM-139 & 0.48 & 0.44 & 0.53 & 0.49 & 1.00 & & \\
RMG-1035 & 0.57 & 0.47 & 0.64 & 0.49 & 0.63 & 1.00 & & \\
RMG-344 & 0.60 & 0.49 & 0.66 & 0.51 & 0.66 & 0.79 & 1.00 & \\
RMG-1045 & 0.60 & 0.52 & 0.58 & 0.48 & 0.61 & 0.80 & 0.74 & 1.00 \\
\hline
\end{tabular}

Figure.1 Protocol used for ISSR primers for PCR amplification

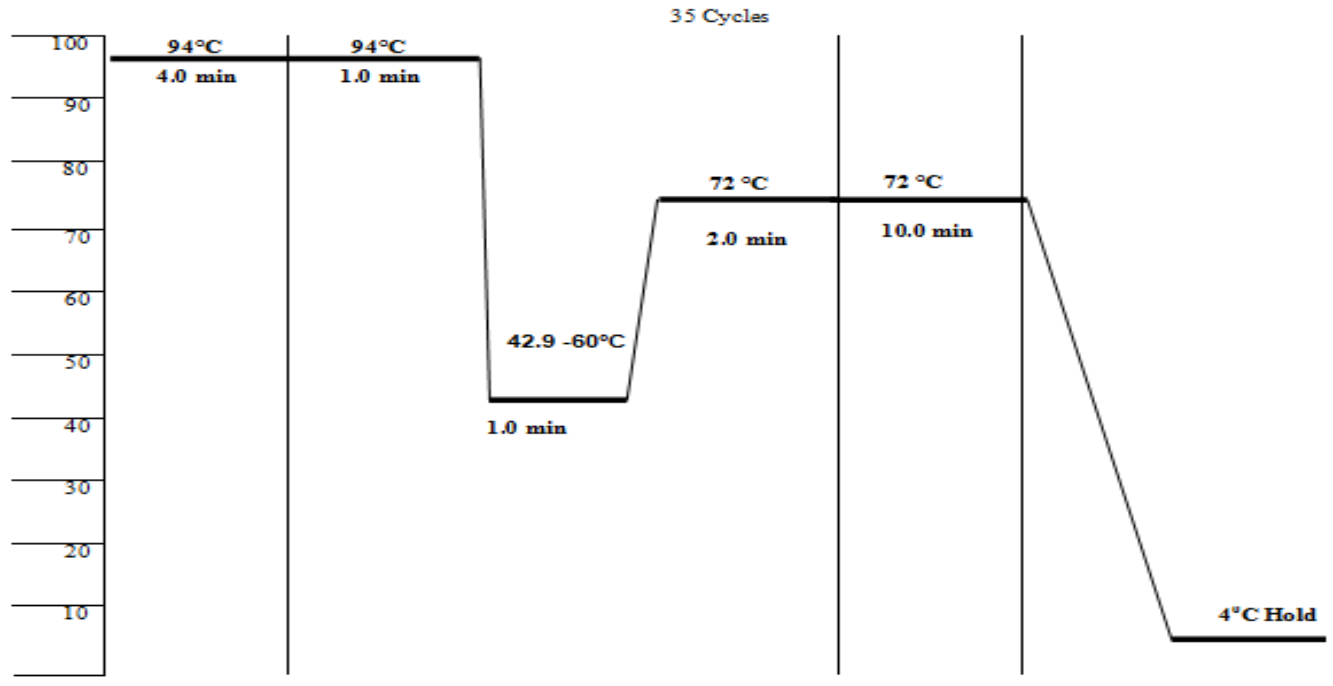


Figure.2 3d ISSR

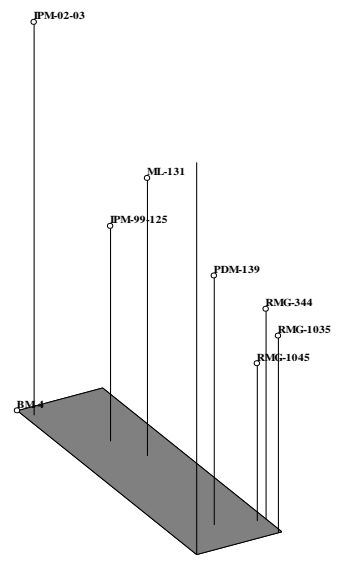

Figure.3 Dendrogram of greengram genotypes using ISSR markers

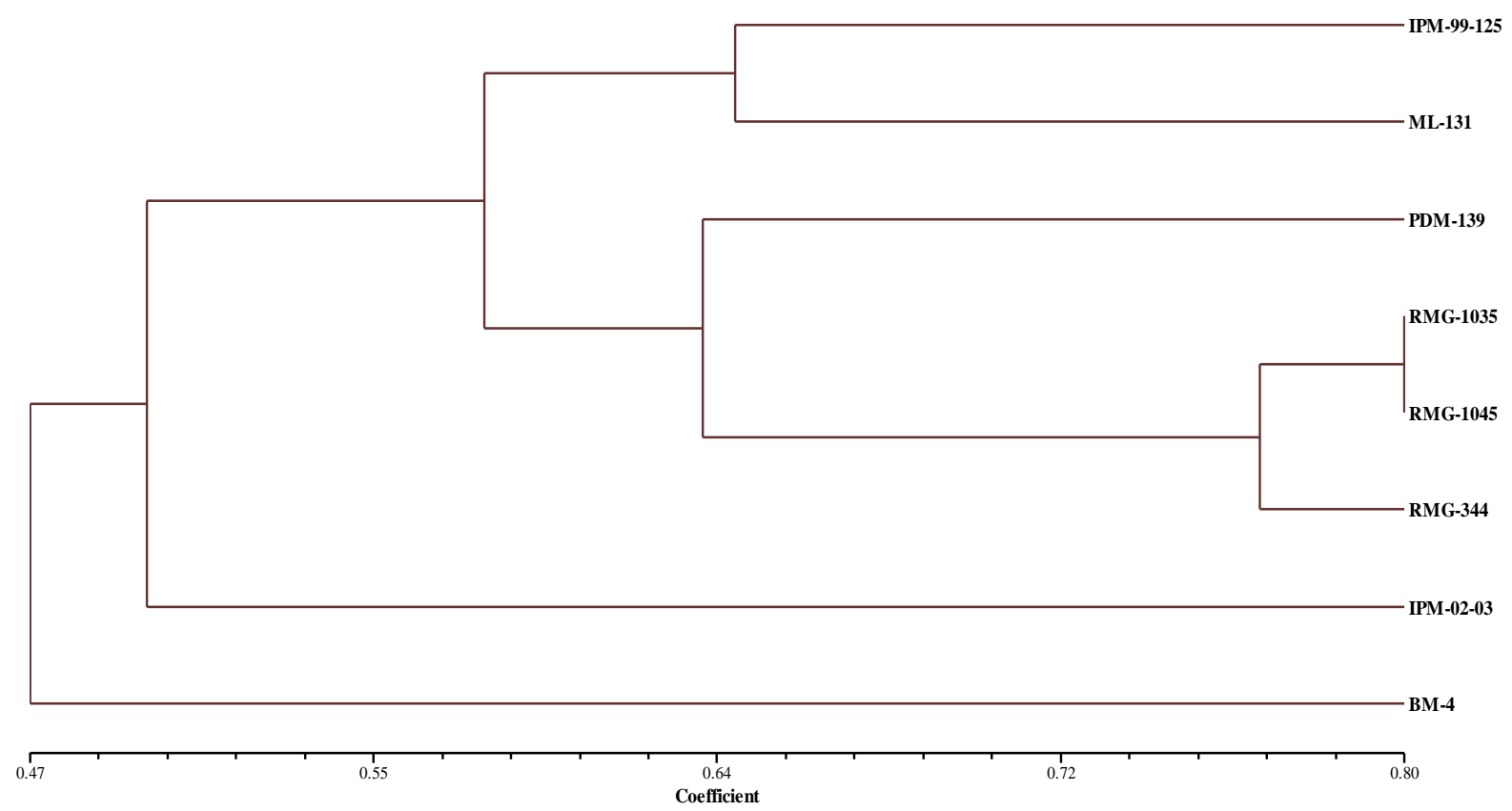

\section{Cluster tree analysis}

The ISSR data based derivation of similarity matrix shown in table 6 reveal the similarity values lay between 0.43-0.80. The dendrogram clearly indicated four major clusters (Fig. 3). Cluster I included two genotypes IPM 99-125 and ML-131 are similar to each other at a similarity coefficient of 0.64. Cluster II is the main one that included four genotypes viz., PDM-139, RMG-1035, RMG-1045 and RMG-344. It could be divided into two, sub-clusters IIA which joined with sub cluster IIA at similarity coefficient of 0.62. Sub-cluster IIA included only one genotype viz. PDM-139. Sub cluster IIB included three genotypes and also divided as IIB 1 and IIB 2. IIB 1 has two genotypes 
RMG-1035 and RMG-1045 are similar to each other at a similarity coefficient of 0.80 , these two genotypes showed the maximum similarity coefficient. Subcluster BII 2 included only one genotype viz. RMG-344. Cluster III and cluster IV included only one genotype IPM 02-03 and BM-4 respectively. Cluster II joined with cluster IV at similarity coefficient of 0.49. Similar results have been reported by Singh et al., (2013). The UPGMA distributed the 30 genotypes into five main clusters; similarity coefficient values ranging from 0.65 to 0.8 . One genotype namely, ML 818 forms an out-group by not falling in any cluster. The genetic variation amongst advanced lines of diverse crosses, also found the same result by Tantasawat et al., (2010) and Bharati et al., (2012).

Molecular analysis through ISSR markers revealed that cross BM 4 and IPM 02-03 followed by BM-4 and PDM-139 has high parental genetic diversity having 57 per cent and 56 per cent dissimilarity respectively. Therefore, the hybrid of BM 4 x IPM 02-03 and BM-4 x PDM-139 turned out to be the most promising on the basis of its parental genetic diversity and high per se performance, in both for seed yield and its components. Therefore this cross can be gainfully utilized.

\section{References}

Bhareti, P., Singh, D.P. and Khulbe, R.K. 2012. Genetic diversity in urdbean [V. mungo (L.) Hepper] revealed by ISSR markers. J. Food Legumes, 25: 89-93.
Chattopadhyay, K., Ali, M.N., Sarkar, H.K., Mandal, N. and Bhattacharyya, S. 2005. Diversity analysis by RAPD and ISSR markers among the selected mungbean (Vigna radiata (L.) Wilckez) genotype. Indian J. Genetics, 65: 172-175.

Das, S., Sur, Das, S.S. and Ghosh, P. 2014. Assessment of molecular genetic diversity in some green gram cultivars as revealed by ISSR analysis. Adv. Appl. Sci. Res., 5: 93-97.

Datta, J. and Lal, N. 2011. Genetic differentiation in Cicer arietinum L. and Cajanus cajan L. Millspaugh using SSR and ISSR marker systems. Adv. Biotech., 11: 39-44.

Singh, R., Heusden, A.W. van and Yadav, R. C. 2013. A comparative genetic diversity analysis in mungbean (Vigna radiata $\mathrm{L}$.) using inter-simple sequence repeat (ISSR) and amplified fragment length polymorphism (AFLP). African $J$. Biotechnol., 12: 6574-6582.

Singh, R., Heusden, A.W.V. and Yadav, R.C. 2011. A comparative genetic diversity analysis in mungbean (Vigna radiata $\mathrm{L}$.) using inter-simple sequence repeat (ISSR) and amplified fragment length polymorphism (AFLP). African $J$. Biotechnol., 12(47): 6574- 6582.

Tantasawat, P., Trongchuen, J., Prajongjai, T., Thongpae, T., Petkhum, C., Seehalak, W. and Machikowa, T. 2010. Variety identification and genetic relationships of mungbean and black gram in Thailand based on morphological characters and ISSR analysis. African J. Biotechnol., 9: 4152-4164.

\section{How to cite this article:}

Anamika Nath, S.R. Maloo, B.L. Meena, A. Gangarani Devi and Sheetal Tak. 2017. Assessment of Genetic Diversity Using ISSR Markers in Green Gram [Vigna radiata (L.) Wilczek]. Int.J.Curr.Microbiol.App.Sci. 6(5): 1150-1158. doi: https://doi.org/10.20546/ijcmas.2017.605.125 